\title{
PENDEKATAN TEKSTUAL DAN KONTEKSTUAL DALAM PENAFSIRAN ALQURAN
}

\author{
M. Solahudin \\ Dosen Fakultas Ushuluddin UIN Sunan Gunung Djati Bandung \\ Jl. AH. Nasution 105 Cibiru Bandung \\ Email: muhammadsolahudin661yahoo.co.id
}

\begin{abstract}
The universality of Qur'anic messages find its significant in facing diverse realities in Muslim society. Thus, it is important to find suitable approaches to understand the Qur'an in order that its messages and values can be actualised in Muslim society. This research describes the prosedures of textual and contextual approaches in understanding the Qur'an to harmonise the messages of the Qur'an into human's life in society. Textual approachfocuses on its text grammatically and literally. Its process reflected from text to praxis (context). Meanwhile, the procedure of contextual approach is tracing its significant in context of revelation and thus need an interdisiplinary study with other sciences.
\end{abstract}

Keywords: textual, contextual, interdisiplinary, interpretation

Keywords:

Text; context; interdiscipline; interpretation.

\begin{abstract}
Abstrak
Pesan-pesan Alquran yang universal seringkali berhadapan dengan realitas kehidupan bermasyarakat yang beragam. Karenanya diperlukan berbagai pendekatan dalam merefleksikan nilai-nilai Alquran agar aktualisasi nilainilai Alquran di dalam masyarakat berjalan seiring dengan keuniversalannya. Penelitian ini berusaha mendeskripsikan kinerja pendekatan tekstual dan kontekstual dalam memahami Alquran, sebagai upaya memahami teks dengan konteks yang harmoni dengan kehidupan masyarakat. Dalam pendekatan tekstual, praktik tafsir lebih berorientasi pada teks yang ada dalam dirinya. Sedangkan dalam pendekatan kontekstual melibatkan pemahaman ekstra-teks bukan intra-teks. Pendekatan tekstual biasanya memfokuskan pembahasannya pada kinerja gramatikal, melalui pemahaman harfiah, sehingga cenderung menggunakan analisis yang bergerak dari refleksi [teks] ke praksis [konteks]. Sedangkan kinerja pendekatan kontekstual berusaha memahami suatu teks dengan cara melacak konteks penggunaannya pada masa ketika teks itu muncul, termasuk situasi dan kondisi di mana ayat Alquran diturunkan, kemudian dipahami secara interdisiplin dengan ilmu-ilmu yang berkembang saat ini.
\end{abstract}

Kata Kunci:

Tekstual; Kontekstual; interdisiplin; Penafsiran.

\section{A. PENDAHULUAN}

Penafsiran Alquran pada dasarnya dilakukan untuk membuka muatan-muatan nilai yang terkandung di dalamnya. Namun untuk menggali muatan-muatan nilai yang terpendam dalam teks-teks Alquran, tidak semua orang dapat melakukannya. Karena ada beberapa persyaratan yang harus dimiliki oleh seorang mufasir, sebagaimana yang kita ketahui dari kesepakatan ulama tafsir dan 'uhūm Al-Qur'àn tentang ketetapan persyaratan yang harus dimiliki oleh seorang mufasir. Para mufasir dari kalangan tradisionalis modern, umumnya dapat dikatakan sebagai mufasir yang memiliki kompetensi dan persyaratan sebagai mufasir. Namun para mufasir dari kalangan tradisionalis pada umumnya masih terjebak pada pembahasan gramatikal bahasa yang cenderung penuh kehati-hatian dan terkadang terkesan kaku. Penafsir pada kelompok ini seakan tidak memiliki peran sebagai anggota sebuah sistem dari kegiatan penafsiran. Penafsir hanya bergerak pada muara yang 
bersifat kearaban yang bermain hanya pada ranah teks. Sebagai akibatnya, mutiara kandungan Alquran yang terpendam pada sistem teks-teks Alquran itu sendiri belum tergali secara mendalam, Alquran menjadi belum fungsional --secara optimal-- sebagai petunjuk. Sehingga wajar, kalau kemudian umat jarang yang menjadikan Alquran sebagai dasar pijakan dalam bertindak dan bersikap. Tanpa disadari, hal ini akan menjadikan Alquran hanya sebagai simbol semata dan menjadikannya sebagai barang antic. Padalah pemahaman terhadap tafsir sangat penting, seperti tafsir modern yang banyak macam ragamnya itu kontekstual sebagai pengembangan setelah memahami makna tekstual ${ }^{1}$.

Dalam 'uhùm al-Qur'ān wa Tafsìr banyak diperkenalkan cara untuk memahami dan menafsirkan Alquran yang tujuannya untuk mengungkap pesan-pesan Alquran. Tentu saja cara-cara mendekati dan memahami Alquran itu berbeda-beda, meskipun intinya adalah bagaimana agar semua umat pada semua tingkatan memiliki akses yang sama terhadap Alquran. Akan tetapi cara-cara untuk memahami dan menafsirkan Alquran sebagaimana yang diperkenalkan oleh para ulama 'uh̄m al-Qur'ān, tidaklah mudah seperti membalikan tangan dalam prakteknya. Siapa pun akan menjumpai kesulitan ketika menjelaskan ayat-ayat Alquran, karena pada satu sisi sang penafsir tetap dituntut memperhatikan teks Alqurandan pada sisi lain harus menyingkronkan teks itu dengan konteks kehidupan masyarakat yang relatif memiliki nuansa yang berbeda.

Polemik antara teks dan konteks juga dikenal dalam uhūm al-Qur'ān. Polemik di sekitar antara teks dan konteks bisa dilihat dari pertanyaan yang sering muncul: Apakah yang harus dipegang adalah teks, konteks, atau tujuan shara? variabel-variabel pertanyaan ini masing-masing memiliki

\footnotetext{
1 Rosihon Anwar, Dadang Darmawan, and Cucu Setiawan, "Kajian Kitab Tafsir Dalam Jaringan Pesantren Di Jawa Barat," Wawasan: Jurnal Ilmiah Agama Dan Sosial Budaya 1, no. 1 (2016): 57-58.
}

jawaban dan masing-masing pendukung, namun jumhur ulama kebanyakan berpegang pada teori pertama, yaitu teks. Apakah juga mungkin dapat disatukan antara teks dan konteks dalam memahami dan menafsirkan Alquran? Bukankah nilai-nilai universal Alquran dan nilai-nilai lokal masyarakat memerlukan proses akulturasi? Untuk menjawab persoalan tersebut dan agar interaksi sebagian umat Islam dengan Alqurantidak hanya terbatas pada keyakinan, membaca, dan mendengarkan, maka penulis merasa sangat perlu untuk membahas bagaimana ayat-ayat Alquran dapat dipahami secara tekstual dan kontekstual.

\section{B. HASIL DAN PEMBAHASAN}

\section{Pendekatan Tekstual dalam Penafsiran}

\section{Alquran}

Sebagaimana yang dikatakan Paul Ricoeur, bahwa teks ${ }^{2}$ adalah wacana (discourse) ${ }^{3}$ yang disusun dalam tulisan. Dari definisi ini, penyusunan (fiksasi) tulisan bersifat konstitusi terhadap teks itu sendiri. ${ }^{4}$ Pendekatan tekstual dalam studi Tafsir merupakan suatu usaha dalam memahami makna tekstual dari ayat-ayat Alquran. Pada pendekatan tekstual, praktik tafsir lebih berorientasi pada teks dalam dirinya. Kontekstualitas suatu teks lebih dilihat sebagai posisi suatu wacana internalnya atau intra-teks. Bahkan pendekatan tekstual

\footnotetext{
${ }^{2}$ Teks merupakan fiksasi atau pelembagaan sebuah wacana lisan dalam bentuk tulisan. Penggunaan kata teks pada al-Qur'an secara sderhana dapat dipahami sebagai tulisan yang telah sampai kepada kita sebagai pembaca; baca mushaf. Permasalahan lebih lanjut adalah bahwa teks atau kalam Allah tidak terbatas pada firman yang telah terekam dan tertulis dalam mushaf saja, melainkan alam raya ini juga merupakan tanda yang jika ditelusuri akan menunjukkan adanya realitas lain yang tidak hadir. Komarudin Hidayat, Memahami Bahasa Agama: Sebuah Kajian Hermeneutik (Jakarta: Paramadina, 1996), 132-135. ${ }^{2}$

Wacana merupakan media untuk proses dialog antara berbagai individu untuk memperkaya pengetahuan dan pemikiran dalam rangka mencari kebenaran tertinggi. Komaruddin Hidayat, Menafsirkan Kehendak Tuhan (Jakarta: Teraju, 2004), 142. ${ }^{3}$

Paul Ricoeur, Hermeneutics and Human Sciences (New York: Cambridge University Press, 1981), 145.
} 
cenderung menggunakan analisis yang bergerak dari refleksi (teks) ke praksis (konteks) yaitu memfokuskan pembahasan pada gramatikal-tekstual. Praksis yang menjadi muaranya adalah lebih bersifat kearaban, sehingga pengalaman sejarah dan budaya di mana penafsir dengan audiennya sama sekali tidak punya peran. Teori ini didukung oleh argumentasi bahwa Alquran sebagai sebuah teks suci telah sempurna pada dirinya sendiri. Pendekatan dari realitas ke teks dalam studi Alquran menjadi sebuah keniscayaan dalam upaya integrasi keilmuan ${ }^{5}$

Terdapat pandangan yang lebih maju dalam konteks ini, yaitu bahwa dalam memahami suatu teks, seseorang harus melacak konteks penggunaannya pada masa di mana teks itu muncul. Sebagaimana Ahsin Muhammad menegaskan bahwa kontekstualisasi pemahaman Alquran merupakan upaya penafsir dalam memahami ayat Alquran bukan melalui harfiah teks, tapi dari konteks dengan melihat faktor-faktor lain, misalnya situasi dan kondisi di mana ayat Alquran diturunkan. Seperti misalnya pengetahuan tentang Gender di dalam alQuran, seperti yang diungkapkan oleh Masripah "The arguments that we see in the Quran and Sunnah generally applicable to both men and women, except for the distinction with her feminine nature backgrounds: in the household, one male and one female." Oleh karenanya, seorang penafsir harus memiliki pemikiran yang luas, misalnya mengetahui hukum Islam secara rinci, mengetahui kondisi pada waktu hukum itu ditetapkan, mengetahui alasan dari suatu hukum yang ditetapkan, dan sebagainya. ${ }^{7}$

\footnotetext{
${ }^{5}$ Syahrullah Iskandar, "Studi Alquran Dan Integrasi Keilmuan: Studi Kasus UIN Sunan Gunung Djati Bandung," Wawasan: Jurnal Ilmiah Agama Dan Sosial Budaya 1, no. 1 (2016): 87.

${ }^{6}$ Masripah, "Indonesian Islamic Women Movement (A Case Study of Bkswi West Java)," International Journal of Nusantara Islam 1, no. 2 (2013): 9-21.

Ahsin Muhammad, "Asbab al-Nuzul dan Kontekstualisasi Al-Qur'an”, Makalah, Fakultas Ushuluddin IAIN Sunan Kalijaga Yogyakarta, (1992), 7.
}

Sebagai contoh, salah satu kitab tafsir yang menggunakan pedekatan tekstual, yang berangkat dari refleksi ke praksis adalah Tafsir Al-Misbah. Tafsir ini ditulis oleh Quraish Shihab sekitar bulan Juni 1999 di Kairo. Kitab Tafsir ini belum mewakili berbagai problem yang dihadapi umat Islam Indonesia. Sebab pada akhir tahun 1990-an, Indonesia mengalami perubahan politik dan dinamika pemahaman keagamaan. Misalnya, kebutuhan yang sangat mendesak untuk kesatuan Indonesia dengan perlunya dibangun hubungan sosial antara umat beragama. Tetapi, nampaknya belum terlihat dengan tegas pembahasan persoalan tersebut di dalam Tafsir Al-Misbah. Sebagai sebuah proses budaya, penafsiran Alquran yang sangat dipengaruhi (jika tidak "dideterminasi") ruang waktu, sangatlah wajar jika melahirkan kera-gaman $^{8}$

\section{Pendekatan Kontekstual dalam Penafsiran Alquran}

Perlu diketahui terlebih dahulu apa maksud dari konteks itu sendiri. Konteks adalah situasi yang di dalamnya suatu peristiwa terjadi, atau situasi yang menyertai munculnya sebuah teks; sedangkan kontekstual artinya berkaitan dengan konteks tertentu. Terminologi kontekstual sendiri memiliki beberapa definisi yang menurut Noeng Muhadjir, setidaknya terdapat tiga pengertian berbeda, yaitu: 1) berbagai usaha untuk memahami makna dalam rangka mengantisipasi problem-problem sekarang yang biasanya muncul; 2) makna yang melihat relevansi masa lalu, sekarang dan akan datang; di mana sesuatu akan dilihat dari titik sejarah lampau, makna fungsional sekarang, dan prediksi makna yang relevan di masa yang akan datang; dan 3) memperlihatkan keterhubungan antara pusat (central) dan pinggiran (periphery) ${ }^{9}$, dalam

8 Muhammad Solahudin, "Metodologi Dan Karakteristik Penafsiran Dalam Tafsir Al-Kashshaf," Wawasan: Jurnal Ilmiah Agama Dan Sosial Budaya 1, no. 1 (2016): 116-117.

${ }^{9}$ Noeng Muhadjir, Metodologi Penelitian Kualitatif (Yogyakarta: Rake Sarasin, 2000), 263-264. 
arti yang sentral adalah teks Alquran dan yang periferi adalah terapannya. Selain itu, arti periferi ini, juga mengandung arti menundukkan Alquran sebagai sentral moralitas. ${ }^{10}$

Pendekatan kontekstual yang dimaksud disini adalah pendekatan yang mencoba menafsirkan Alquran berdasarkan pertimbangan analisis bahasa, latar belakang sejarah, sosiologi, dan antropologi yang berlaku dalam kehidupan masyarakat Arab pra-Islam dan selama proses wahyu Alquran berlangsung. Selanjutnya, penggalian prinsipprinsip moral yang terkandung dalam berbagai pendekatan. Secara substansial, pendekatan kontekstual ini berkaitan dengan pendekatan hermeneutika, yang merupakan bagian di antara pendekatan penafsiran teks yang berangkat dari kajian bahasa, sejarah, sosiologi, dan filosofis. ${ }^{11}$

"Al-Quran as the first and the foremost guidance for Muslims" ${ }^{\text {;2 }}$. Selain itu, permasalahan di tengah manusia seperti yang diungkapkan Saputra bahwa "The spiritual crisis of modern human beings here means, firstly, that they say people can no more live in hope of religion as life guidance as it prevent as well as resist progression; and secondly, that it is the believers of religion who do crime on behalf of God or religious teaching ${ }^{13}$." Sehingga, untuk memahami ayatayat Alquran sangatlah penting, dan tidak hanya dipahami dengan pendekatan tekstual saja, tetapi kondisi-kondisi yang terkait dengan turunnya ayat juga menjadi sesuatu yang sangat penting dalam memahami ayat-

10 Noeng Muhadjir, Metodologi Penelitian Kualitatif......., 263-264.

${ }^{11}$ Richard E. Palmer, Hermeneutics: Interpretation Theory in Schleiermacher, Dilthey, Heidegger, and Gadamer (Evanston: Northwestern University Press, 1969), 34-45.

${ }^{12}$ Fenti Hikmawati, "Islamic Counselling Model to Increase Religious Commitment (Study of Students at the University UIN Bandung)," International Journal of Nusantara Islam 1, no. 1 (2013): 65-81.

${ }^{13}$ Riki Saputra, "Religion And The Spiritual Crisis Of Modern Human Being In The Perspective Of Huston Smith 'S Perennial Philosophy," Al-Albab 5, no. 2 (2016): 195-215. ayat Alquran. Dimana keterlibatan kondisikondisi tersebut menjadi titik acuan dalam memahami ayat-ayat Alquran dengan menggunakan pendekatan kontekstual. Dalam hal ini, Muhammad Abduh (w. 1905 M.), seperti dikutip Munawir Sjadjali, mengingatkan kepada kita agar berhati-hati dalam membaca karya-karya tafsir terdahulu, karena penulisannya berlangsung dalam suasana dan tingkat intelektual masyarakat yang pasti belum tentu sama dengan zaman sekarang. Oleh sebab itu, Abduh menganjurkan agar mengkaji langsung pesan Alquran dan jika memungkinkan membuat karya tafsir sendiri. Namun bila yang terakhir ini ingin diwujudkan, seseorang harus memiliki kemampuan bahasa yang memadai, memahami sejarah Nabi terutama situasi kultural masyarakat dimana Alquran diturunkan, dan menguasai sejarah umat manusia secara umum. ${ }^{14}$ Menurut penulis, disinilah letak perbedaan antara pendekatan kontekstual dan tematik. Di mana di satu sisi, pada metode tematik asbā b al-Nuzūl hanya dipahami sebagai alat bantu untuk memahami ayat Alquran . Sementara di sisi lain, pada pendekatan kontekstual tidak saja mengkaji $a s b \bar{a} b$ al-nuz̄ $l$, tetapi juga menyelidiki latar belakang sosiologis-antropologis masyarakat tempat Alquran diturunkan. Dalam hal ini, Amin al-Khuli (1895-1966 M) dan Fazlur Rahman (1919-1988 M), meski keduanya tidak pernah menghasilkan karya tafsir, ${ }^{15}$ barangkali perlu dicatat sebagai tokoh dari

14 Munawir Sjadzali, "Ijtihad dan Kemaslahatan Umat", dalam Haidar Bagir dan Syafiq Basri (ed.), Ijtihad dalam Sorotan (Bandung: Mizan, 1988), 121.

${ }^{15}$ Maksudnya literatur tafsir yang menafsirkan ayat al-Qur'an, baik berdasarkan urutan surat yang ada dalam mushaf, maupun surat-surat yang terpisah-pisah sebagaimana ditulis oleh para ulama klasik dan modern. Namun, apabila yang dimaksud adalah menulis tafsir di luar pengertian tersebut, maka karya Fazlur Rahman yang berjudul Major Themes of the Qur'an (Tema Pokok Al-Qur'an) dapat disebut sebagai karya tafsir, dan bahkan M. Quraish Shihab dkk, menempatkan karya seperti ini dalam kelompok karya tafsir yang menggunakan metode tematik.M. Quraish Shihab, et. al, Sejarah dan 'Ulüm al-Qur'ān, ed. Azyumardi Azra (Jakarta: Pustaka Firdaus, 1999), 194. 
sekian tokoh yang menggagas perlunya penafsiran Alquran menggunakan pendekatan kontekstual. Penggunaan pendekatan kontekstual dalam penafsiran Alquran adalah upaya untuk memahami ayat-ayat Alquran dengan memperhatikan dan mengkaji konteks atau aspek-aspek di luar teks yang dihubungkan dengan peristiwa-peristiwa atau keadaan-keadaan yang menyebabkan turunnya suatu ayat, apa latar belakang historis, geografis, sosial budaya, hukum kausalitas, dan sebagainya. ${ }^{16}$ Jadi, kajian ayat-ayat Alquran secara kontekstual erat hubungannya dengan pemahaman asbāb nuzūl al-āayat. Meskipun pada kenyataannya tidak semua ayat memiliki asbāb al-nuzūl, yang membuat status ayat bersifat umum atau bersifat khusus. Oleh karena itu, dengan mengetahui kondisi yang menyebabkan turunnya ayat Alquran akan dapat menentukan dengan mudah apakah ayat tersebut dapat dipahami dengan pendekatan tekstual ataukah dengan pendekatan kontekstual. Yang menjadi persoalan sekarang adalah bagaimana menentukan mana yang tekstual dan mana yang kontekstual. ${ }^{17}$

Aturan yang ditetapkan Allah SWT. pada umumnya mudah dipahami dan dijalankan oleh umat Islam yang belatar belakang budaya dan bangsa yang berbeda-beda. ${ }^{18}$ Sepanjang yang diketahui, tidak ada ulama yang mengatakan bahwa semua ajaran Islam harus dipahami secara kontekstual. Dalam hal ini para ulama telah membagi doktrin Islam kedalam ma'qūl al-ma'na dan ghayr ma'qūl al-ma'na atau ta'aqquli dan ta'abbudi. Pada tahapan ini, semua setuju bahwa masalahmasalah yang ta'abbudi tidak harus dipahami secara kontekstual. Sebagaimana dijelaskan

16 Abudin Nata, Peta Keagamaan PemikiranPemikiran Islam di Indonesia (Jakarta: Raja Grafindo Persada, 2001), 107-110.

17 Nuraini, Otentisitas Sunnah: Analisis Pemikiran Fazlur Rahman (Yogyakarta: AK Group dan Ar-Raniry Press, 2006), 42.

${ }^{18}$ Utami, "Community In Dividing The Inheritance Amicably (Study in Palangka Raya City Jekan Raya Districts)," Jurnal Studi Agama Dan Masyarakat 10, no. 2 (2016): 275-299.
M. Quraish Shihab, sikap ini diambil oleh Abu Hānifah (w. 150 H.) --yang biasanya sangat bebas dalam pemahamannya-- seperti pada masalah tamattu: Beliau menyatakan bahwa denda (dam) tidak boleh dibayar dengan uang, tapi harus dibayar dengan darah mengalir, sebab dia berfikir bahwa persoalan tersebut bersifat ta'abbudi. ${ }^{19}$

Pada dasarnya pendekatan kontekstual ini cenderung menggunakan analisis yang bergerak dari praksis ke refleksi. Analisis ini mengandung arti bahwa pemahaman Alquran secara konteks merupakan usaha dari seorang mufasir dalam memahami ayat-ayat Alquran, melalui konteks dari ayat-ayat Alquran itu sendiri, dengan melihat kondisi dan situasi di mana dan karena alasan apa ayat-ayat Alquran itu diturunkan ${ }^{20}$. Hal yang penting diperhatikan juga, ialah harus ditarik ke dalam konteks penafsir di mana ia hidup dan berada, dengan pengalaman sejarah, sosial, dan budayanya sendiri. Lebih jauh dapat dikatakan, bahwa hubungan teks dengan konteks, sebagaimana yang dinyatakan Komarudin Hidayat bahwa bahasa dan budaya sesungguhnya tidak bisa dipisahkan. Setiap teks muncul dalam sebuah wacana yang memiliki banyak variabel, antara lain suasana politis, ekonomis, psikologis dan lain sebagainya. Sehingga ketika wacana yang bersifat spontan dan dialogis dituliskan dalam teks maka sangat potensial akan melahirkan pemahaman yang salah di kalangan pembacanya. Setidaknya, pengetahuan yang diperoleh melalui sebuah lisan akan berada dari pengetahuan yang didapat melalui bacaan. $^{21}$ Oleh sebab itu, karya terjemahan dan penafsiran yang hanya terpaku pada gramatikal bahasa akan kehilangan banyak dimensi teks yang sangat fundamental.

${ }^{19}$ M. Quraish Shihab, "Hubungan H adith dengan Al-Qur'an: Tinjauan Segi Fungsi dan Makna," dalam Yunahar Ilyas dan M. Mas'udi (ed.), Pengembangan Pemikiran Terhadap Hadith (Yogyakarta: LPPI, 1996), 77.

20 Solahudin, "Metodologi Dan Karakteristik Penafsiran Dalam Tafsir Al-Kashshaf."

${ }_{21}$ Komarudin Hidayat, Memahami Bahasa Agama....., 17. 
Salah satu contoh yang dianggap baik dalam penggunaan pendekatan kontekstual ini adalah Farid Esack. Ia menempatkan hermeneutik Alquran dalam ruang sosial di mana ia berada, sehingga sifatnya bukan lagi kearaban yang bersifat umum. $^{22}$ Esack merumuskan hermeneutik Alquran yang berporos pada pembebasan dan persamaan dengan mempertimbangkan aspek kontekstual di mana ia hidup. Menurut Esack, tidak ada tafsir dan ta'wil yang bebas nilai. Penafsiran Alquran, bagaimanapun, adalah eisegesis -memasukkan wacana asing ke dalam Alquran- sebelum exegesis --mengeluarkan wacana dari Alquran . ${ }^{23}$

Contoh tafsir lainnya adalah Tafsir Tematik Alquran Tentang Hubungan Sosial Antar Umat Beragama karya Majelis Tarjih dan Pengembangan Pemikiran Islam PP. Muhammadiyah. Sebagaimana yang dinyatakan oleh Syafi'i Ma'arif, bahwa buku tafsir tersebut merupakan bentuk kegelisahan dan sumbangan pemikiran bagi bangsa Indonesia yang carut marut dalam masalah hubungan antarumat beragama. Dengan mengatasnamakan agama, harta benda, kehormatan, bahkan nyawa sekalipun sudah banyak berjatuhan. ${ }^{24}$

Dalam buku tafsir tersebut digambarkan bahwa perbedaan dan keragaman agama merupakan kenyataan dan keniscayaan yang mesti terjadi. Lebih lanjut buku tafsir tersebut juga menyatakan bahwa yang harus dimiliki oleh setiap pemeluk masing-masing agama adalah kesadaran untuk merefleksikan dan

22 Louis Brenner, "Introduction" dalam Louis Brenner (ed.) Muslim Identity and Social Change in Sub-Saharian Africa (London: Hurs and Company, 1993), 5-6.

${ }^{23}$ Farid Esack, "Contemporary Religious Thought in South Africa and The Emergence of Qur'anic Hermeneutical Notions", dalam ICMR., Vol. 2, no. 2, Desember 1991. Secara teoritik dan praktik lihat Farid Esack, Qur'an Liberation and Pluralism: An Islamic Perspective of Interrelegious Solidarity Againt Oppression (Oxford: Oneworld, 1997), 49-77.

${ }^{24}$ Tim Majlis Tarjih dan Pengembangan Pemikiran Islam PP. Muhammadiyah, Tafsir Tematik Al-Qur'an Tentang Hubungan Sosial Antar umat Beragama (Yogyakarta: Pustaka SM, 2000), vi. memahami kembali ajaran-ajaran kitab sucinya, baik berkenaan dengan moralitas, education, teologi, dan hukum. Buku tafsir inipun dapat digolongkan sebagai reaksi dan refleksi dari keadaan dan carut marutnya berbagai persoalan yang dihadapi oleh bangsa Indonesia. Bagi penulis, buku tafsir tersebut patut untuk dijadikan sebagai suatu upaya solutif untuk bagaimana suatu ajaran kitab suci mampu menuangkan benih-benih kasih sayang dan benih-benih perdamaian di bumi Nusantara ini, bahkan tidak jarang kitab suci hanya dijadikan alat legitimasi tindak kekerasan, anarki, pembenaran kebijakan yang timpang, dan melanggengkan kekuasaan yang otoriter.

Contoh tafsir yang menggunakan pendekatan kontekstual selanjutnya adalah buku tafsir karya Syu'bah Asa yang berjudul Dalam Cahaya Alquran, Tafsir Ayat-Ayat Sosial Politik. Karakteristik buku tafsir tersebut yaitu pada setiap ayat dikemukakan dan digerakan dalam ranah peristiwa, waktu, dan tempat di mana ia berada sebagai bentuk respon terhadap peristiwa yang terjadi. ${ }^{25}$ Warna lainnya bahwa setiap ayat menurutnya merupakan cahaya yang menyoroti kejadiankejadian yang sedang terjadi dan populer di dalam ruang sosial keindonesiaan. Karenanya Syu'bah merupakan tokoh pemerhati Islam yang berusaha membaca dan mengikuti lajunya zaman --yang terkadang tidak lagi bersahabat-- dari sudut pandang Alquran . Karenanya Kuntowijoyo, menyebut buku tafsir tersebut sebagai tafsir yang sesuai dengan jiwa-zaman. ${ }^{26}$

Syu'bah dalam buku tafsir tersebut berusaha memosisikan Alquran sebagai kritik sosial. Dimana pada saat tafsir tersebut

${ }^{25}$ Kuntowijoyo dalam kata pengantarnya atas buku Syu'bah ini menyebutnya sebagai tafsir yang menggunakan pendekatan historis, yaitu menyatu dengan waktu dan tempat. Kuntowijoyo, "Pengantar" dalam Syu'bah Asa, Dalam Cahaya Al-Qur'an (Jakarta: Gramedia, 2000), ix.

${ }^{26}$ Kuntowijoyo, "Pengantar" dalam Syu'bah Asa, Dalam Cahaya Al-Qur'an (Jakarta: Gramedia, 2000), $\mathrm{x}$. 
ditulis, berbagai tuntutan agar bangsa Indonesia berbenah diri, memperbaiki sistem ekonomi, pranata sosial, penegakkan hukum, pendidikan secara sistemik, dan keadilan. Tafsir Syu'bah ini bergerak dari praksis ke reflektif. Oleh karena itu, ketika membaca tafsir yang menggunakan pendekatan kontekstual, kita harus teliti mencari hal-hal yang umum dari pernyataan-pernyataan yang khusus. Bila melihat buku tafsir Syu'bah ini, kita bisa saja menuduh bahwa tafsir dengan menggunakan pendekatan kontekstual ini sebagai bentuk dari politisasi Alquran . Akan tetapi, hal yang sangat mendasar untuk dipahami adalah bila setiap kritik sosial yang didasarkan pada ajaran Alquran dianggap (diklaim) sebagai politisasi Alquran, tentu Alquran hanya akan menjadi kitab dokumen yang pasif, yang tidak ada hubungannya dengan perilaku nyata. Bila direnungkan lebih dalam, justru di sinilah letak kekuatan Alquran , karena teks Alquran senantiasa valid dan selalu memiliki keselarasan dalam kritik sosial, baik secara proses maupun kenyataan akhirnya. Kekuatan nilai-nilai dan ajaran Alqurandapat didekati dengan berbagai pendekatan, tanpa memilah-milah dan memilih-milih siapa yang harus mendekatinya. Alquran sebuah kitab suci yang tidak akan pernah berubah, baik secara teks maupun secara konteks, meskipun orang yang mendekatinya dan mempelajarinya serta menafsirkannya memiliki latar belakang kompetensi dan nuansa keilmuan yang beragam. Justru di sinilah letak kekuatan dan kemu'jizatan Alquran, yang tidak akan punah dimakan zaman. Hasyim Asy'ari perlu memberikan penjelasan kepada umat Islam tentang pentingnya memegang teguh ajaran agama Islam yang bersumber dari Alquran dan Hadis dan menjauhkan dari perbuatanperbuatan yang tidak sesuai dengan sumber ajaran Islam di atas. ${ }^{27}$

${ }^{27}$ Afriadi Putra, "Pemikiran Hadis KH. M. Hasyim Asy'ari Dan Kontribusinya Terhadap Kajian Hadis Di Indonesia," Wawasan: Jurnal Ilmiah Agama Dan Sosial Budaya 1, no. 1 (2016): 52.

\section{Nuansa Tafsir}

Nuansa tafsir merupakan ruang dominan sebagai sudut pandang dari suatu karya tafsir. Di antara nuansa tafsir yang penulis ketahui adalah nuansa kebahasaan, nuansa teologi, nuansa psikologis, nuansa sosial, dan sebagainya.

\section{a. Nuansa Kebahasaan}

Sebagai sebuah kitab teks suci, ketika Alqurandiwahyukan dan dibaca oleh Nabi, secara langsung sebenarnya telah tertransformasi dari sebuah teks Ilahi menjadi sebuah konsep atau teks insani. Karena secara langsung berubah dari wahyu menjadi interpretasi. $^{28}$ Kemudian makna-makna yang dikonsepsikan harus dilihat dari konteks bahasa Arab, sebagai bahasa yang digunakan dalam teks Alquran. Dengan demikian, analisis bahasa menjadi sangat urgen dan signifikan.

Sebagai contoh dari nuansa tafsir kebahasaan, terutama di Indonesia, adalah Tafsir Alquran Al-Karim, karya Quraish Shihab, merupakan karya tafsir Indonesia yang kuat dan dominan nuansa kebahasaannya dibandingkan dengan karya tafsir Indonesia lainnya. Hal itu terbukti dari metode penafsirannya, di mana setiap kata dalam ayat Alquran yang akan ditafsirkannya, dianalisis dari segi kebahasaan: diuraikan asal-usul katanya, keragaman maknanya, perubahannya, serta bangunan semantiknya dengan kata-kata yang lain. Sebagai contoh ketika Quraish Shihab menafsirkan ayat 1 surah Al-Fatihah. Rangkaian kata dalam ayat tersebut diuraikannya secara rinci. Mulai dari bi (ب) yang dimaknainya dengan kata "dengan", menurut Quraish Shihab terdapat makna yang tersimpan dari kata yang tidak terucapkan tetapi mesti terlintas di dalam benak, ketika mengucapkan bismillah, yaitu kata "memulai". Sehingga bismillah berarti "saya atau kami ". Dengan begitu, kalimat tersebut menjadi semacam do'a atau

\footnotetext{
${ }^{28}$ Abu Zayd, Naqd Al-Khit\}ab Al-Dini (Kairo: Sina li al-Nas \}r, 1992), 126.
} 
pernyataan dari si pengucap. ${ }^{29}$ Kemudian ia menguraikan kata ism (إِنْ) yang menurutnya

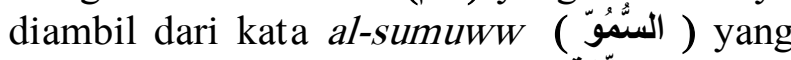
berarti "tinggi" atau al-simah (الستِّمَة (السنة ) yang berarti "tanda". Kata ini bisa diterjemahkan dengan "nama". Namun disebut ism, karena ia seharusnya dijunjung tinggi atau karena ia menjadi tanda bagi sesuatu. Nama adalah hakikat sesuatu yang dinamai itu. Bila dikatakan "dengan nama Allah", maka itu berarti "dengan Allah". 30

Selanjutnya Quraish menjelaskan kata Allah sebagai kata yang ketiga dalam ayat 1 surah Al-Fatihah, di mana kata Allah ini diulang dalam Alquransebanyak 2698 kali, Quraish Shihab mengurainya dalam beberapa pandangan. Ada yang menganggap kata ini berakar dari kata walaha (وكلَة ) yang berarti "mengherankan", atau "menakjubkan". Jadi, Tuhan dinamai Allah karena segala perbuatan-Nya akan mengherankan si pembahas sendiri, dalam arti hakikat zat-Nya. Pendapat lainnya mengatakan bahwa kata tersebut diambil dari kata aliha-ya'lahu ( آلِّة ( يَألهُ ) dalam arti "menuju" dan "bermohon". Tuhan dinamai Allah karena seluruh makhluk menuju serta bermohon kepada-Nya dalam memenuhi kebutuhannya. Sedangkan pendapat lain mengatakan, bahwa kata tersebut pada mulanya berarti "menyembah" atau "mengabdi" sehingga Allah adalah "Zat yang berhak disembah dan kepada-Nya tertuju segala pengabdian". ${ }^{31}$

Dengan dimikian, kata ilah mencakup semua objek sesembahan atau semua yang dianggap sebagai yang menguasai hidup dan mati segala sesuatu. Apabila zat yang disembah itu merupakan zat yang wajib wujud-Nya, wajib untuk disembah, maka Dialah yang oleh Alqurandinamai Allah. $^{32}$

${ }^{29}$ M. Quraish Shihab, Tafsir Al-Qur'an Al-Karim Tafsir atas Surat-Surat pendek Berdasarkan Urutan Turunnya Wahyu (Bandung: Putaka Hidayah, 1997), 8.

${ }^{30}$ M. Quraish Shihab, Tafsir Al-Qur'an Al-Karim Tafsir...., 8 .

31 M. Quraish Shihab, Tafsir Al-Qur'an Al-Karim Tafsir....,12.

32 M. Quraish Shihab, Tafsir Al-Qur'an Al-Karim Tafsir...,12.

\section{a. Nuansa Psikologis}

Yang dimaksud dengan nuansa psikologis adalah suatu nuansa tafsir yang analisisnya menekankan pada dimensi psikologi manusia. Banyak kitab tafsir atau karya buku tafsir yang mengkaji dan menjelaskan nilai-nilai yang terkandung dalam ayat-ayat Alquran , dengan menggunakan dimensi psikologi manusia dalam penafsirannya. Di antara buku tafsir yang termasuk dalam nuansa psikologis terutama tafsir Indonesia adalah Jiwa dalam Alqurankarya Mubarok.

Pada awalnya, penulis buku tafsir ini memusatkan kajiannya pada term nafs dalam Alqurandengan berbagai variasi dan medan semantiknya. Kata nafs dalam bahasa Arab, memiliki banyak arti, misalnya "ruh, diri manusia, hakikat sesuatu, darah, saudara, kepunyaan kegaiban, jasad, kedekatan, zat, kebesaran, dan sebagainya. ${ }^{33}$ Akan tetapi yang menjadi objek dalam kajian Mubarok adalah nafs yang dimaksud dalam Alquran . ${ }^{34}$

Dalam konteks manusia, term nafs oleh Alquran digunakan untuk menyebut manusia sebagai totalitasnya, baik manusia sebagai makhluk yang tinggal di dunia ataupun manusia yang nanti hidup di akhirat. Dalam QS Al-Ma'idah [5]: 32, misalnya menggunakan kata nafs untuk menyebut totalitas manusia di dunia, yakni manusia hidup yang bisa dibunuh, tapi dalam QS Yasin [36]: 54, kata nafs digunakan untuk menyebut manusia di alam akhirat. ${ }^{35}$ Sedangkan pengertian lainnya yang dituangkan Mubarok dalam buku tafsirnya adalah nafs sebagai sisi dalam manusia. Hal itu tersirat dalam QS Al-Ra'd [13]:10 bahwa manusia memiliki sisi-dalam dan sisi-luar. Jika sisi-luarnya dapat dilihat pada perbuatan lahirnya, maka sisi-dalamnya, menurut Alquranberfungsi sebagai penggeraknya. Dalam QS Al-Shams [91]:7 secara tegas menyebut nafs sebagai jiwa. Dengan

33 Ibn Manz\}ur, Lisan Al-'Arab (t.tp.: Dar AlMa‘ārif, t.th.), VI, 4500-4501.

34 Achmad Mubarok, Jiwa Dalam Al-Qur'an (Jakarta: Paramadina, 2000), 43.

${ }^{35}$ Achmad Mubarok, Jiwa Dalam Al-Qur'an......., 46. 
demikian, sisi-dalam manusia adalah jiwanya. Sebagai jiwa inilah dalam konteks nafs diurai fungsi-fungsinya, yaitu penggerak tingkah laku, kapasitasnya, dan kualitasnya. ${ }^{36}$

\section{b. Nuansa Sosial-Kemasyarakatan}

\section{Yang}

kemasyarakatan adalah tafsir yang menitikberatkan penjelasan ayat Alqurandari: 1) ketelitian redaksinya, 2) menyusun kandungan ayat-ayat dalam suatu redaksi dengan tujuan utama memaparkan tujuantujuan Alquran, dan 3) penafsiran ayat dikaitkan dengan sunnatullah yang berlaku dalam masyarakat. ${ }^{37}$ Sebagaimana yang dilakukan Muhammad Abduh --yang menginginkan para pembaca Alquran , masyarakat awam maupun ulama, menyadari relevansi terbatas yang dimiliki tafsir-tafsir tradisional yang tidak akan memberikan pemecahan terhadap masalah-masalah penting yang mereka hadapi setiap harinya-- bahwa nuansa tafsir sosial kemasyarakatan ingin menghindari adanya kesan cara penafsiran yang seakan-akan menjadikan Alquran terlepas dari akar sejarah kehidupan manusia, baik secara individu maupun kelompok. Studi Alquran dapat mendukung upaya integrasi keilmuan dengan cara akomodasi penemuan ilmiah yang sistematis dengan tetap mengacu pada basis kewahyuan Alquran. ${ }^{38}$

Sebagai contoh dari literatur tafsir yang bernuansa sosial-kemasyarakatan adalah buku Tafsir bi al-Ma'thur yang disusun oleh Jalaluddin Rahmat. Dengan metode riwayatnya, Jalal menampilkan nuansa sosialkemasyarakatan dalam tafsirnya sangat ekspresif dan memikat. Tanpa terjebak pada perdebatan pendapat para ulama, yang terkadang menyulitkan pembaca, Jalal melakukan sosialisasi pesan-pesan Alqurandengan gaya bahasanya yang

\footnotetext{
${ }^{36}$ Achmad Mubarok, Jiwa Dalam Al-Qur'an....5358.

${ }^{37}$ M. Quraish Shihab, "Metode Penyusunan Tafsir yang Berorientasi Pada Sastra, Budaya dan Kemasyarakatan”, Makalah, 1984, 1.

38 Iskandar, "Studi AlQuran Dan Integrasi Keilmuan: Studi Kasus UIN Sunan Gunung Djati Bandung.".87-88.
}

memikat. Misalnya ketika Jalal menguraikan surah Al-Fatihah, ia menyampaikan pesan moral Alquranyang terkandung dalam AlFatihah dengan bahasa yang tegas, dan menekankan pentingnya melakukan segala sesuatu atas dasar nama "Allah". Lebih lanjut Jalal mengatakan dalam tafsirnya, bahwa mengurus orang tua, mengelola upah buruh, menghindari maksiat, dan membaca buku adalah hal-hal yang biasa. Tapi menurutnya, semua perbuatan di atas akan mendatangkan kemuliaan apabila dilakukannya atas dasar nama "Allah". Inilah pesan moral Al-Fatihah menurutnya. 39

\section{Pendekatan Interdisipliner sebagai Upaya Memahami Teks secara Kontekstual}

Penafsiran Alquran dengan menggunakan pendekatan berbagai disiplin ilmu telah banyak dilakukan oleh para pengkaji Alquran. Berikut ini akan dikemukakan beberapa contoh penafsiran Alquran dengan menggunakan berbagai pendekatan. Di ant aranya :

\section{a. Penafsiran yang menggunakan pendekatan ilmu bahasa}

Sebagai contoh penafsiran Q.S. alNisa (4): 155;

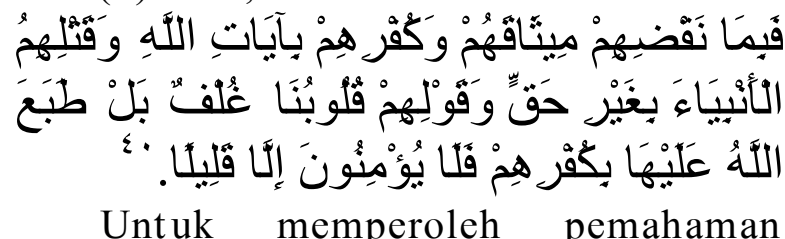

yang mendalam terhadap ayat ini diperlukan perenungan kembali terhadap kalimat (فبما نقضهم), karena pemahaman sepintas secara stailistika akan bertanya,

\footnotetext{
39 Jalaluddin Rahmat, Tafsir bi al-Ma'thur, Pesan Moral Al-Qur'an I (Bandung: Rosdakarya, 1993), 12.

${ }^{40}$ Artinya: "Maka (Kami lakukan terhadap mereka beberapa tindakan), disebabkan mereka melanggar perjanjian itu, dan karena kekafiran mereka terhadap keterangan-keterangan Allah dan mereka membunuh nabi-nabi tanpa (alasan) yang benar dan mengatakan: "Hati kami tertutup." Bahkan, sebenarnya Allah telah mengunci mati hati mereka karena kekafirannya, karena itu mereka tidak beriman kecuali sebagian kecil dari mereka."
} 
kenapa terdapat huruf Lo pada kalimat tersebut? ${ }^{41}$

Sebagian ulama, menurut para mufasir, telah menyatakan bahwa huruf tersebut adalah tambahan; zâidah, padahal tidak boleh mengatakan bahwa di dalam firman Allah (al-Qur'an) terdapat huruf zâidah, artinya bahwa makna akan sempurna sekalipun tanpa keberadaan huruf tersebut dan huruf itu tidak memiliki arti dan faidah serta tidak diperlukan.

Dalam menghadapi ayat seperti itu, jika tidak mampu memahaminya harus

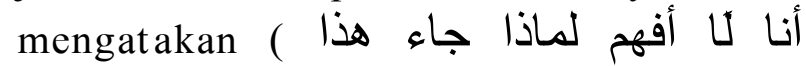
الحرف); aku tidak tahu mengapa ada huruf ini, khususnya bagi mereka yang hidup pada zaman dimana bahasa dihasilkan dengan cara belajar dan tidak memiliki watak bahasa secara spontan. Seandainya tidak belajar bahasa Arab maka siapa pun tidak akan mampu berbahasa Arab. Adapun orang-orang Arab yang hidup pada waktu diturunkannya al-Qur'an, mereka mampu berbahasa Arab tanpa belajar pada seorang guru, mereka tidak belajar bahwa fâ'il itu marfü' dan maf'ûl itu manshûb melainkan mereka berbahasa dengan watak dan tabi'atnya. ${ }^{42}$

Selanjutnya dapat dijelaskan aspek kebahasaan dari ayat di atas secara rinci, bahwa firman Allah (فبما نقضهم), menurut sebagian ulama pada asalnya adalah (بنقضهم الميثاق), mengapa ada huruf مان Sebagian ulama mengatakan bahwa s

\footnotetext{
${ }^{41}$ Al-Sha'rawi, Tafsir al-Sha'rawi, juz V, hal. 2781.

42 Adapun orang yang hidup di zaman yang berbeda, dimana ketidakfasihan menjadi hal yang dominan dan kesalahan bahasa ada dimana-mana sehingga kita diharuskan untuk belajar kaidahkaidah bahasa Arab untuk dapat berbahasa yang baik. Kaidah-kaidah dalam ilmu nahwu yang ada sekarang diambil dari orang-orang Arab terdahulu. Demikian penjelasan al-Sya'râwî ketika memberikan pemahaman terhadap ayat di atas. AlSha'rawi, Tafsir al-Sha'rawi, juz V, hal. 2782.
}

tersebut adalah zâidah, yaitu huruf tambahan yang berfungsi untuk menguatkan. Para mufasir berkali-kali menyatakan, jangan sekali-kali kita menyatakan bahwa di dalam al-Qur'an ada huruf zâidah. Huruf L pada kalimat tersebut mengandung makna yang jelas, dimana pada ayat yang lain (Q.S. alMa'idah (5): 19) Allah berfirman مَا جَاءَنَا منْ بَثَيْر وَّا نَذِير : Para ulama menyatakan bahwa asal ungkapannya adalah مَا جَاءَنَا dan huruf مَثِيِر adalah zâidah agar ungkapannya menjadi serasi. Para mufasir mengatakan bahwa seandainya ungkapan itu sesuai dengan apa yang mereka katakan, maka makna ayat tersebut tidak akan lurus.

Untuk menjelaskan semua hal tersebut, penulis perlu memberikan contoh sebagai berikut: seseorang disaat mengatakan (ما عندى مال) mengandung makna bahwa dia tidak mempunyai harta meskipun tidak menutup kemungkinan bahwa dia mempunyai harta yang tidak pantas dikatakan harta. Tetapi, jika seseorang menyatakan (ما عندى مال) artinya bahwa dia sama sekali tidak mempunyai harta, dia tidak memiliki sedikit pun apa yang disebut harta. Jadi ungkapan (ما جاء نا بشير) tidak seperti ungkapan (ما جاء نا من بشير), maknanya tidak datang kepada mereka sama sekali yang dinamakan Rasul yang memberi kabar baik dan kabar buruk. Jadi meskipun firman Allah (مبما نقضهه بrtinya menurut mereka ( بسبب (ميثاقهم (نقض الميثاق); dengan sebab membatalkan perjanjian. Mengapa mereka memfilsafatinya? Apakah karena ada huruf ما الباء dan setelah huruf dan . Padahal huruf L pada ayat

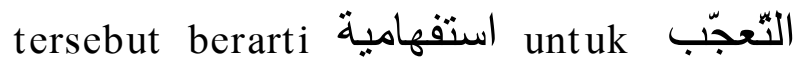
Achmad Mubarok, Jiwa Dalam Alquran yang maknanya dalam bentuk apa dari segala 
bentuk pembatalan terhadap janji mereka? Karena mereka terlalu banyak melanggar perjanjian. Jadi mereka membatalkan perjanjian dengan segala bentuknya. ${ }^{43}$

\section{b. Penafsiran yang menggunakan pendekatan ilmu pengetahuan alam}

Sebagai contoh penafsiran Q.S. Fâthir (35): 27;

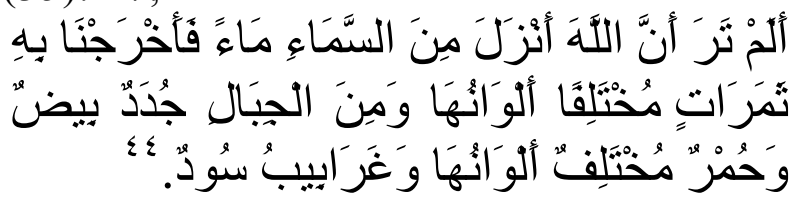

Dalam menafsirkan ayat di atas, para mufasir menjelaskan bahwa Allah SWT. telah mengingatkan kita atas sebagian nikmat yang telah diberikan-Nya kepada kita dan kemudian menyusulnya dengan memberikan sebagian tuntutan. Begitulah Allah meyakinkan dan memberikan rasa tentram kepada hati kita agar kita dapat melaksanakan tuntutan tersebut.

Pada saat Allah mengingatkan hambahamba-Nya dengan ayat kauniyah ini, yaitu tentang diturunkannya hujan dari langit, sebelumnya Allah menjelaskan terlebih dahulu ancaman bagi orang-orang kafir, seakan-akan Allah ingin menyatakan dengan susunan seperti itu kepada Rasul-Nya: Biarlah kamu jangan memikirkan tentang orang-orang kafir karena Aku berkuasa untuk menyiksa mereka, tetapi renungkanlah ayat kauniah ini:

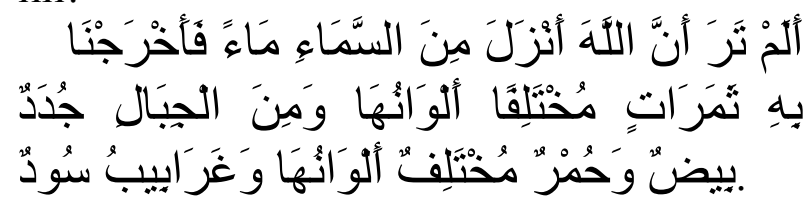

43 Al-Sha'rawi, Tafsir al-Sha 'rawi, juz V, hal. 2784.

44 Artinya: "Tidaklah kamu melihat bahwasanya Allah menurunkan hujan dari langit lalu Kami hasilkan dengan hujan itu buah-buahan yang beraneka macam jenisnya. Dan di antara gunung-gunung itu ada garisgaris putih dan merah yang beraneka macam warnanya dan ada (pula) yang hitam pekat. Dan demikian (pula) diantara manusia, binatang-binatang melata, dan binatang-binatang ternak ada yang bermacam-macam warnanya (jenisnya). Sesungguhnya yang takut kepada Allah diantara hamba-hamba-Nya hanyalah ulama. Sesungguhnya Allah Maha Perkasa lagi Maha Pengampun.”
Selanjutnya para mufasir menjelaskan bahwa kalimat تشناهد ألٌْ تَرَ artinya apakah kamu tidak menyaksikan, karena semua orang melihat hujan turun dari atas. السماءadalah sesuatu yang ada di atas kita dan menaunginya. Terkadang

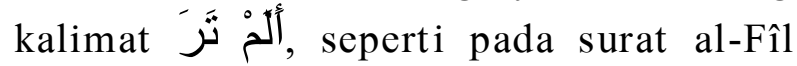
(105): 1, berarti ألم تعلم dan makna itu ditunjukkan bagi sesuatu yang tidak dilihat oleh Rasulallah. Maka penggunaan khitab dengan kalimat أَلْْم تَرَ dimaksudkan untuk memberikan pemahaman bahwa pemberitaan Allah tentang kejadian itu terpercaya dan benar adanya dibanding hanya penglihatan mata saja.

Yang dimaksud turun hujan dari alsamâ' adalah dari arahnya, karena hujan itu diturunkan dari awan yang jaraknya tidak jauh dari bumi. Proses turun hujan dari langit nampaknya hanya kejadian alam biasa, dimana akibat proses pemanasan air menguap ke atas dan menjadi gumpalan awan dan akibat berat dayanya air turun ke bumi dengan daya tarik bumi. Setelah itu Allah menjelaskan

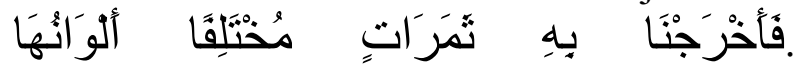
Seandainya tetap bahwa proses turun hujan dianggap proses alam biasa, bagaimana dengan proses penyuburan tanah dan pertumbuhan bermacam-macam tanaman dan buah-buahan, apakah hal itu masih proses alam biasa juga? ${ }^{45}$

Kata أنزل, menurut mufasir, hubungan dengan kalimat sebelumnya, mengandung arti tingginya yang menurunkan dan rendahnya yang diturunkan, meskipun teknis kejadiannya terbalik dari bawah ke atas, sebagaimana firman Allah Q.S. al-

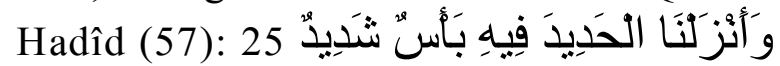
وَمَنَافِعُ لِلنَّاس. Besi pada kenyataannya dikeluarkan dari perut bumi tetapi dinyatakan إنزال; diturunkan, karena yang dimaksud adalah dilakukan dari atas

45 Al-Sha'rawi, Tafsir al-Sha'rawi, juz XX, hal. 12491. 
ke bawah tanpa melihat arahnya, baik atas maupun bawah. Proses turunnya hujan dari atas ke bawah dapat disaksikan tetapi tidak bisa menyaksikan proses penguapan air dari laut kemudian naik kelapisan udara di atas dan membentuk awan dengan cara penebalan. Tidak ada seorang pun mengetahui tentang proses ini meskipun telah majunya ilmu pengetahuan dan hanya tahu proses turunnya hujan. ${ }^{46}$

Konteks ayat di atas dalam pandangan para mufasir dapat dijadikan petunjuk bahwa Allah ketika menjelaskan tentang turunnya hujan dari langit menggunakan ungkapan kalimat أنزل dengan dlamir ghaib, sedangkan ketika membicarakan tentang mengeluarkan buah-buahan فأخرجنا menggunakan ungkapan kalimat dengan menggunakan dlamir jama' mutakallim yang menunjukkan تعظبر, memiliki pengertian bahwa turunnya hujan dari langit bukan sesuatu yang utama dan penting, dengan alasan bahwa hujan terkadang turun ke tanah yang gersang dan tandus sehingga tidak bermanfaat. Adapun proses mengeluarkan buah-buahan adalah proses yang sangat penting dari tujuan diturunkannya hujan. Oleh sebab itu, menggunakan dlamir jama' mutakallim yang menunjukkan تعظيم semakna dengan firman Allah dalam Q.S. al-Hijr (15): 9;

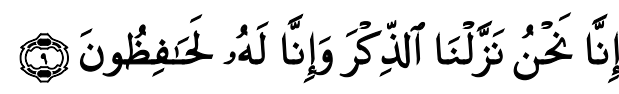

\section{!Penafsiran yang menggunakan pendekatan ilmu pendidikan}

Di antara penafsiran yang berkaitan dengan ilmu pengajaran (ilmu pendidikan) adalah penafsiran Q.S. Ali Imran (3): 59;

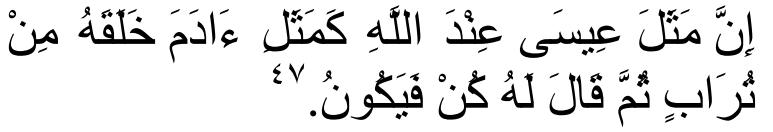

46 Al-Sha'rawi, Tafsir al-Sha'rawi, juz XX, hal. 12492.

47 Artinya: "Sesungguhnya misal (penciptaan) 'Isa di sisi Allah, adalah seperti (penciptaan) Adam. Allah
Dalam pandangan para mufasir, penafsiran al-Qur'an dari segi ajaran (pendidikan) dapat diambil dari penjelasan al-Qur'an tentang proses penciptaan Isa a.s. dimana kelahiran Isa a.s. terus menjadi perdebatan, sekalipun hal itu telah dijelaskan Allah di dalam al-Qur'an. Hanya saja, pemahamannya tidak bisa sebatas memahami proses penciptaan Isa a.s. melainkan harus dipahami dari proses penciptaan Adam a.s. atau proses penciptaan manusia, sehingga pada akhirnya diperoleh letak ajarannya yang dikandungnya.

Menurut para mufasir, manusia pertama yang diciptakan Allah SWT. adalah Adam a.s. Ia diciptakan dengan kata S dari Allah. Adam tercipta dengan tidak memiliki ayah dan ibu, karena sebelumnya Allah tidak menciptakan manusia. Adam langsung diciptakan Allah tanpa laki-laki dan tanpa perempuan. Hal ini tentunya menjadi kemu'jizatan pertama dalam penciptaan manusia. Sesuai dengan tujuan penciptaan manusia, untuk melestarikan kehidupan dan memperbanyak keturunan, Allah menciptakan segala sesuatu dari lakilaki dan perempuan. Untuk itu, Allah terlebih dahulu menciptakan Hawa dari tulang rusuk Adam atau dari bagian diri Adam. Hal ini merupakan kemu'jizatan kedua dalam penciptaan manusia. Yaitu menciptakan manusia dari laki-laki tanpa perempuan. Selanjutnya proses penciptaan manusia terlahir dari hasil perkawinan antara laki-laki dan perempuan. Begitu pula yang terjadi pada makhluk hidup lainnya seperti hewan yang terlahir dan berkembang biak dari hasil perkawinan antara jantan dan betina, atau tumbuhan yang tumbuh kembang dari hasil proses

menciptakan Adam dari tanah, kemudian Allah berfirman kepadanya: "Jadilah" (seorang manusia), maka jadilah dia." 
tumpang sari, baik dalam satu bunga atau melalui angin antara satu bunga dengan bunga lainnya. Proses penciptaan ini merupakan kemu'jizatan yang ketiga dalam proses penciptaan manusia. ${ }^{48}$

Penjelasan tentang proses penciptaan manusia melalui tiga bentuk di atas dalam pandangan al-Sya'râwî menjadi alasan bagi Allah untuk menyempurnakan kemu'jizatannya dengan membuat penciptaan manusia dengan proses yang berbeda dari sebelumnya, yaitu menciptakan manusia hanya dari perempuan tanpa laki-laki. Proses ini yang terjadi pada Isa a.s. Penciptaan makhluk adalah hak mutlak Allah, tidak disertai oleh siapapun. Hal ini menunjukkan bahwa penciptaan manusia, sekalipun melalui proses perkawinan antara laki-laki dan perempuan, tetap tunduk kepada kemutlakan kehendak Allah Swt. طلاقة (القدرة اله تعالى (اله ), karena bisa jadi perkawinan laki-laki dan perempuan tidak melahirkan keturunan.

\section{c. Penafsiran yang menggunakan pendekatan ilmu sosial}

Sebagai contoh penafsiran dengan menggunakan pendekatan ilmu sosial adalah penafsiran Q.S. Al-Ma'un (107):1-7;
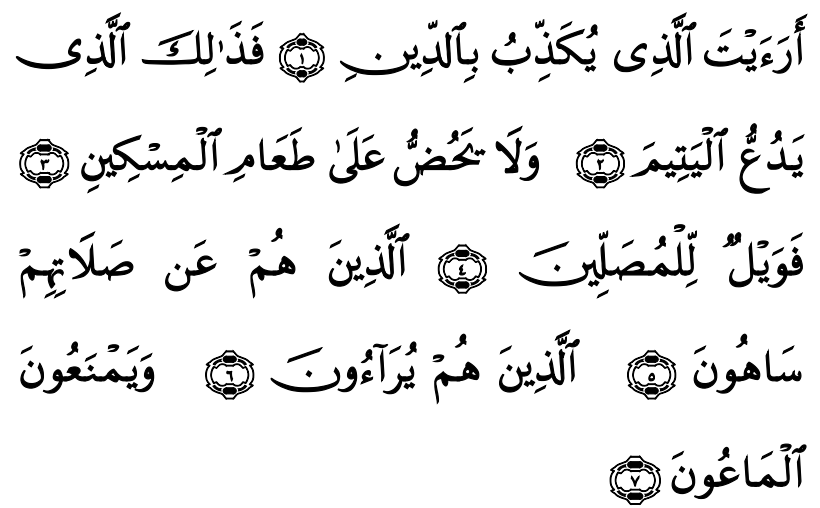

Terdapat 95 kali dalam 38 surat, penyebutan kata din dan derivasinya

48 Al-Sha'rawi, Tafsir al-Sha'rawi, juz III, hal. dalam Alquran . Kata din memiliki makna kontekstual yang berbeda-beda. Secara ringkas dapat diungkap bahwa pada periode Makkah awal, kata din berarti pembalasan dan akhirat atau pembalasan kelak di akhirat. Makna ini diperkenalkan kepada masyarakat Arab yang mengalami kemajuan dan kemakmuran dan perdagangan yang aman, tetapi mereka mempraktekkan ekonomi oligopolis dan monopolis serta praktek-praktek ekonomi tak bermoral lainnya. Kehidupan mereka sangat sekuler. Orientasi hidupnya hanya di dunia. Mereka berorientasi dalam bidang ekonomi hanya untuk mengumpulkan keuntungan yang setinggi-tingginya.

Dalam surat al-Ma'un ini diawali oleh pertanyaan, tetapi pertanyaan tersebut tidak menuntut jawaban. Maksud pertanyaan tersebut hanya untuk menggugah hati dan pikiran teman bicara, agar memperhatikan kandungan pembicaraan. Inti dalam surat ini adalah untuk mengajak manusia agar menyadari salah satu bukti utama kesadaran beragamanya. Dijelaskan pula dalam surat ini, bahwa kesadaran dan keberagamaan seseorang harus dibuktikan dengan sikap batin dan lahir yang tereksplor dalam bentuk tindakan nyata. Bila tidak terbukti tindakan nyata dalam perbuatan, dianggap dan dinilai mendustakan agama.

Adapun bukti-bukti kebohongan keberagamaan seseorang sebagaimana yang dijelaskan dalam surat ini adalah sebagai berikut: Pertama, menghardik anak yatim atau mendorong dengan keras, baik secara fisik maupun mental untuk tidak memperdulikan anak-anak terlantar, anak-anak jalanan, anak-anak yang kehilangan kasih sayang orang tuanya, serta orang-orang lemah (lemah fisik dan ekonomi); Kedua, tidak menganjurkan untuk memberi makan orang miskin. Maksud dari ayat ini adalah bukan memberi makan, tetapi menganjurkan 1462. 
memberi makan. Logikanya, orang yang tidak memiliki banyak harta dan makanan pun dituntut untuk berperan dalam menganjurkan memberi makan. Oleh karenanya, peran ini bisa dilakukan oleh siapapun. Dengan demikian, inti dari pada ayat ini adalah mendidik dan mengajarkan kepada setiap orang untuk empati (ikut merasakan sebagaimana yang dialami penderitanya terhadap orang miskin. Lebih jauh ayat ini menegaskan bahwa setiap orang yang menganjurkan dan memberi makan tidak merasa bahwa ia telah memberi makan terhadap orang lain yang butuh, sebab ayat ini menggunakan redaksi to'am bukan 'it'am. Ini menunjukkan bahwa makanan yang diberikan, meskipun dari tempat penyimpanan, pada hakekatnya bukan dari miliknya, tetapi merupakan hak orang-orang miskin dan butuh.

Kemudian dijelaskan pada ayat berikutnya bahwa orang yang wajib shalat, tetapi tidak melaksanakannya atau melakukan shalat tetapi tidak menghayati tujuan shalatnya, maka orang tersebut diancam dengan kebinasaan dan kecelakaan. Banyak orang yang melakukan shalat, tetapi sedikit orang yang mendirikan shalat. Dalam Alquran, orang-orang yanmg seperti itu, digambarkan sebagai orang yang 'riya' yang menghalangi pemberian bantuan. Hal tersebut sebagai tanda bagi orang yang tidak menghayati makna dan tujuan shalat, karena shalat merupakan refleksi dan aktualisasi dari sikap lemah dan butuhnya manusia kepada Tuhan sekaligus menunjukkan keagungan dan kebesaran-Nya.

Dari pemaparan di atas dapat disimpulkan bahwa pengalaman keagamaan tidak selalu bersifat personal, tapi juga harus terwujud dalam kehidupan sosial, baik secara individu maupun kelompok.

\section{SIMPULAN}

Dalam melakukan penafsiran terhadap ayat-ayat Alquran, di satu sisi penafsir hendaknya berusaha mendeskripsikan pesanpesan dari teks atau ayat yang ditafsirkannya, berdasarkan ciri atau sifat khas yang dimiliki oleh bahasa Alquranitu sendiri. Akan tetapi di sisi lain, penafsir juga diperbolehkan untuk menggunakan berbagai pendekatan keilmuan yang dijadikan kerangka berfikir dalam menafsirkan ayat-ayat Alquran, agar pesanpesan yang terkandung dalam ayat-ayat Alqurandapat terefleksikan dengan baik pada umat secara menyeluruh. Baik dengan pendekatan ilmu kebahasaan, ilmu alam, ilmu pendidikan, ilmu sosial, dan sebagainya. Meskipun demikian, berbagai pendekatan dan disiplin ilmu yang digunakan oleh penafsir, itu tidak boleh keluar dari kerangka sistem bahasa dan apa yang diinginkan oleh pesanpesan Alquranitu sendiri. Sebab, jika hal itu terjadi, maka inti dari pesan-pesan Alqurantentu tidak akan sampai sebagai ajaran kebenaran yang universal kepada umat manusia, sehingga pesan Alquranmenjadi tergantung pada siapa saja yang ingin menafsirkannya secara personal.

Demikian pembahasan singkat tentang penafsiran Alqurandengan menggunakan pendekatan interdisiplin ilmu. Dengan segala kekurangannya, semoga makalah ini dapat bermanfaat. Amin.

\section{DAFTAR PUSTAKA}

Anwar, Rosihon, Dadang Darmawan, and Cucu Setiawan. "Kajian Kitab Tafsir Dalam Jaringan Pesantren Di Jawa Barat." Wawasan: Jurnal Ilmiah Agama Dan Sosial Budaya 1, no. 1 (2016): 56-69.

Brenner, Louis. "Introduction" dalam Louis

Brenner (ed.). Muslim Identity and Social Change in Sub-Saharian Africa. London: Hurs and Company, 1993.

Esack, Farid. "Contemporary Religious Thought in South Africa and The Emergence of Qur'anic Hermeneutical 
Notions". dalam ICMR. Vol. 2, no. 2. Desember 1991.

Hidayat, Komarudin. Memahami Bahasa Agama: Sebuah Kajian Hermeneutik. Jakarta: Paramadina, 1996.

Hikmawati, Fenti. "Islamic Counselling Model to Increase Religious Commitment (Study of Students at the University UIN Bandung)." International Journal of Nusantara Islam 1, no. 1 (2013): 65-81.

Iskandar, Syahrullah. "Studi AlQuran Dan Integrasi Keilmuan: Studi Kasus UIN Sunan Gunung Djati Bandung." Wawasan: Jurnal Ilmiah Agama Dan Sosial Budaya 1, no. 1 (2016): 13-14.

Kuntowijoyo. "Pengantar" dalam Syu'bah Asa. Dalam Cahaya Alquran . Jakarta: Gramedia, 2000.

Manzur, Ibn. Lisan Al-'Arab. t.tp.: Dar AlMa'ārif, t.th. VI.

Masripah. "Indonesian Islamic Women Movement (A Case Study of Bkswi West Java)." International Journal of Nusantara Islam 1, no. 2 (2013): 9-21.

Mubarok, Achmad. Jiwa Dalam Alquran Jakarta: Paramadina, 2000.

Muhadjir, Noeng. Metodologi Penelitian Kualitatif. Yogyakarta: Rake Sarasin, 2000.

Muhammad, Ahsin. "Asbab al-Nuzul dan Kontekstualisasi Alquran ". Makalah, Fakultas Ushuluddin IAIN Sunan Kalijaga Yogyakarta, 1992.

Muhammadiyah, Tim Majlis Tarjih dan Pengembangan Pemikiran Islam PP. Tafsir Tematik AlquranTentang Hubungan Sosial Antarumat Beragama. Yogyakarta: Pustaka SM, 2000.

Nata, Abudin. Peta Keagamaan PemikiranPemikiran Islam di Indonesia. Jakarta: Raja Grafindo Persada, 2001.

Nuraini. Otentisitas Sunnah: Analisis Pemikiran Fazlur Rahman. Yogyakarta: AK Group dan Ar-Raniry Press, 2006.

Palmer, Richard E. Hermeneutics. Interpretation Theory in Schleiermacher, Dilthey, Heidegger, and Gadamer.
Evanston: Northwestern University Press, 1969.

Pluralism: An Islamic Perspective of Interrelegious Solidarity Againt Oppression. Oxford: Oneworld, 1997.

Putra, Afriadi. "Pemikiran Hadis KH. M. Hasyim Asy'ari Dan Kontribusinya Terhadap Kajian Hadis Di Indonesia." Wawasan: Jurnal Ilmiah Agama Dan Sosial Budaya 1, no. 1 (2016): 46-55.

Rahmat, Jalaluddin. Tafsir bi al-Ma'thur, Pesan Moral AlquranI. Bandung: Rosdakarya, 1993.

Ricoeur, Paul. Hermeneutics and Human Sciences. New York: Cambridge University Press, 1981.

Saputra, Riki. "Religion And The Spiritual Crisis Of Modern Human Being In The Perspective Of Huston Smith S S Perennial Philosophy." Al-Albab 5, no. 2 (2016): 195-215.

Shihab, M. Quraish. Tafsir AlquranAl-Karim Tafsir atas Surat-Surat pendek Berdasarkan Urutan Turunnya Wahyu. Bandung: Putaka Hidayah, 1997.

"Metode Penyusunan Tafsir yang Berorientasi Pada Sastra, Budaya dan Kemasyarakatan”. Makalah. 1984. et. al. Sejarah dan 'Ulum alQur'an, ed. Azyumardi Azra. Jakarta: Pustaka Firdaus, 1999.

"Hubungan Hadith dengan Alquran : Tinjauan Segi Fungsi dan Makna," dalam Yunahar Ilyas dan M. Mas'udi (ed.). Pengembangan Pemikiran Terhadap Hadith. Yogyakarta: LPPI, 1996.

Sjadzali, Munawir. "Ijtihad dan Kemaslahatan Umat", dalam Haidar Bagir dan Syafiq Basri (ed.). Ijtihad dalam Sorotan. Bandung: Mizan, 1988.

Solahudin, Muhammad. "Metodologi Dan Karakteristik Penafsiran Dalam Tafsir AlKashshaf." Wawasan: Jurnal Ilmiah Agama Dan Sosial Budaya 1, no. 1 (2016): 116-26.

Utami. "Community In Dividing The Inheritance Amicably (Study in Palangka 
Raya City Jekan Raya Districts).” Jurnal Studi Agama Dan Masyarakat 10, no. 2 (2016): 275-99.
Zayd, Abu. Naqd Al-Khitab Al-Dini. Kairo: Sina li al-Nasr, 1992. 